\title{
Financial Stability dan Misstatement Laporan Keuangan dengan Opportunity Fraud sebagai Variabel Moderating
}

\author{
Kadek Yoga Suryawan ${ }^{1}$ \\ Fakultas Ekonomi dan Bisnis \\ Universitas Udayana, Indonesia
}

\author{
I Gusti Ayu Nyoman Budiasih² \\ Fakultas Ekonomi dan Bisnis \\ Universitas Udayana, Indonesia
}

Surel : yogasuryawan267@gmail.com

\section{ABSTRAK}

Penelitian bertujuan untuk memperoleh bukti empiris pengaruh Financial Stability pada Misstatement Laporan Keuangan dan untuk mengetahui kemampuan Opportunity Fraud memoderasi pengaruh Financial Stability pada Misstatement Laporan Keuangan. Penelitian ini dilakukan pada Bursa Efek Indonesia (BEI) yang memiliki data-data keuangan perusahaan khususnya perusahaan manufaktur. Metode penentuan sampel menggunakan teknik purposive sampling. Jumlah sampel dalam penelitian ini adalah sebanyak 308 data observasi. Teknik analisis yang digunakan adalah Moderated Regression Analysis (MRA). Hasil penelitian menunjukan bahwa Financial stability berpengaruh positif pada misstatement laporan keuangan perusahan manufaktur yang terdaftar di BEI tahun 2015-2018 dan Opportunity Fraud memperlemah pengaruh Financial Stability pada Misstatement Laporan Keuangan perusahaan manufaktur yang terdaftar di BEI tahun 2015 - 2018.

Kata Kunci: Pengalaman; Kompetensi; Independensi; Fee Audit; Kualitas Audit.

\section{Financial Stability and Misstatement of Financial Statements with Opportunity Fraud as Moderating Variable}

\begin{abstract}
The research aims to obtain empirical evidence of the influence of Financial Stability on Misstatement of Financial Statements and to determine the ability of Opportunity Fraud to moderate the influence of Financial Stability on Misstatement of Financial Statements. This research was conducted at the Indonesia Stock Exchange (IDX) which has corporate financial data, especially manufacturing companies. The method of determining the sample using a purposive sampling technique. The number of samples in this study were 308 observational data. The analysis technique used is Moderated Regression Analysis (MRA). The results showed that Financial stability had a positive effect on the misstatement of financial statements of manufacturing companies listed on the Indonesia Stock Exchange in 2015-2018 and Opportunity Fraud weakened the influence of Financial Stability on the Misstatement of Financial Statements of manufacturing companies listed on the Indonesia Stock Exchange in 2015 - 2018.
\end{abstract}

Keywords: Experience; Competence; Independence; Audit Fees; Quality Audits.

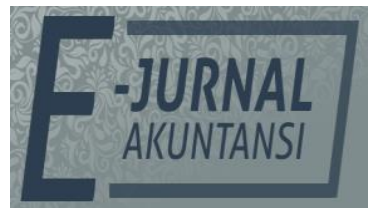

e-ISSN 2302-8556

Vol. 31 No. 9

Denpasar, September 2021 Hal. 2182-2194

DOI:

10.24843/EJA.2021.v31.i09.p03

PENGUTIPAN:

Suryawan, K.Y., \& Budiasih,

I.G.A. (2021). Financial Stability dan Misstatement Laporan Keuangan dengan Opportunity Fraud sebagai Variabel Moderating. E-Jurnal Akuntansi, 31(9), 2182-2194

RIWAYAT ARTIKEL:

Artikel Masuk: 8 Januari 2020 Artikel Diterima: 15 September 2021

Artikel dapat diakses : https://ojs.unud.ac.id/index.php/Akuntansi/index 


\section{PENDAHULUAN}

Selama hampir satu dekade belakangan ini terdapat dua jenis kejahatan yang menggemparkan dunia adapun dua jenis kejahatan tersebut yaitu terorisme dan kejahatan keuangan yang berupa fraud atau dikenal dengan praktik kecurangan dalam penyajian laporan keuangan perusahaan. Hampir sebagian besar perusahaan di Indonesia khususnya perusahaan yang telah Go Public menginginkan kondisi keuangan perusahaan dalam keadaan yang baik dan stabil, hal ini secara tidak langsung menjadi beban dan tantangan tersendiri bagi perusahaan agar tidak tergiur dengan melakukan tindakan manipulasi pada laporan keuangan guna untuk memenuhi target tertentu suatu perusahaan. Pada umumnya Manajemen Perusahaan melakukan manipulasi laporan keuangan agar performa perusahaan terlihat meningkat dan lebih baik, dan mengesampingkan keadaan perusahaan sebenarnya yang menjadikan menurunnya tingkat kepercayaan investor dan stakeholder (Rohana et al., 2012). Untuk itu suatu audit dirancang untuk memberikan keyakinan bahwa laporan keuangan tidak dipengaruhi oleh salah saji (misstatement) yang material dan memberikan keyakinan atas akuntanbilitas manajemen atas aktiva perusahaan (Koroy, 2008).

Hasil penelitian yang dilakukan oleh Association of Certified Fraud Examiners (2002) menunjukan bahwa 58 persen dari kasus kecurangan yang dilaporkan dilakukan oleh karyawan pada tingkat manajerial. 36 persen dilakukan oleh manajer tanpa melibatkan orang lain dan 6 persen dilakukan oleh manajer dengan melakukan kolusi bersama karyawan. Sepanjang tahun 2014, terdapat 777 pelaku pasar modal yang dikenai sanksi oleh Otoritas Jasa Keuangan (OJK). Atas pelanggaran itu, OJK menerapkan sanksi administratif berupa denda kepada emiten senilai Rp7,9 miliar. Kepala Eksekutif Pengawas Pasar Modal, Otoritas Jasa Keuangan, Nurhaida mengungkapkan, 777 sanksi itu terdiri dari 60 sanksi peringatan tertulis, 713 sanksi denda, 2 sanksi pencabutan izin, dan 2 sanksi pembekuan izin (Viva News, 30 Desember 2014). Berdasarkan realitas atas sanksi yang dikeluarkan OJK sebagaimana diberitakan dalam Viva News, menunjukkan bahwa terdapat kegagalan audit dalam mendeteksi adanya kecurangan laporan keuangan.

Kecurangan yang terjadi di Indonesia bisa saja tidak hanya terjadi pada satu sektor saja, melainkan pada beberapa sektor lain, seperti kasus yang terjadi pada PT Kimia Farma Tbk (PT KF). PT Kimia Farma adalah badan usaha milik Negara yang sahamnya telah diperdagangkan di bursa efek Indonesia. Berdasarkan indikasi oleh Kementerian BUMN dan pemeriksaan Bapepam Bapepam, (2002) ditemukan adanya salah saji dalam laporan keuangan yang mengakibatkan lebih saji (overstatement) laba bersih untuk tahun yang berakhir 31 Desember 2001 sebesar Rp 32,7 miliar yang merupakan 2,3 persen dari penjualan dan 24,7 persen dari laba bersih. Salah saji ini terjadi dengan cara melebih sajikan penjualan dan persediaan pada 3 - 5 unit usaha, dan dilakukan dengan menggelembungkan harga persediaan yang telah diotorisasi oleh Direktur Produksi untuk menentukan nilai persediaan pada unit distribusi PT Kimia Farma per 31 Desember 2001. Selain itu manajemen PT Kimia Farma melakukan pencatatan ganda atas penjualan pada 2 unit usaha. Pencatatan ganda itu dilakukan pada unit-unit yang tidak disampling oleh auditor eksternal (Koroy, 2008). Beberapa kasus besar di Indonesia berdasarkan catatan Indonesia Police Watch (IPW) dikutip 
Indahrini \& Darman (2011) antara lain yaitu adanya kasus yang terjadi di PT. Jamsostek pada tahun 2002 dengan kerugian mencapai Rp 45 miliar, proyek peningkatan akademik di Departemen Pendidikan Nasional (2005) dengan kerugian mencapai Rp 6 miliar, dan beberapa kasus kecurangan lainnya yang penyelesaiannya masih terkatung-katung.

Prayogi (2010) mengatakan bahwa Bursa Efek Indonesia (BEI) menjatuhkan sanksi denda sebesar Rp 500 juta dan surat peringatan tertulis ketiga kepada empat emiten yang melaukan kesalahan penyajian laporan keuangan kuartal I tahun 2010, yaitu PT. Bakrie Sumatera Plantation Tbk (UNSP), PT Energi Mega Persada Tbk (ENRG), PT Benakat Petroleum Energy Tbk (BIPI) dan PT Bakrie Brothers Tbk (BNBR). Karena pada emiten tersebut tidak segera merevisi laporan keuangan triwulan I tahun 2010 yang salah walaupun mereka sudah menyadari kesalahan tersebut. BEI menilai keempat emiten memiliki permasalahan dalam laporan mereka karena perbedaan pencatatan pada laporan keuangan dengan kenyataan. Kasus dana siluman beberapa emiten Group Bakrie tersebut dan PT Benakat Petroleum Energy Tbk (BIPI) di Pt Bank Capital Tbk (BACA) dinilai perlu melibatkan institusi Pusat Pelaporan dan Analisis Transaksi Keuangan (PPATK). Masih banyak kasus kecurangan yang dilakukan oleh sejumlah perusahaan publik yang terdeteksi oleh Badan Pengawas Pasar Modal (BAPEPAM). Meskipun beberapa salah saji belum tentu terkait dengan kecurangan tetapi faktor - faktor resiko yang berkaitan dengan kecurangan oleh manajemen terbukti ada pada kasus - kasus tersebut.

Untuk mengatasi kelemahan dalam prosedur pendeteksian kecurangan, American Institute of Certified Public Accountants (AICPA) menerbitkan Statement on Auditing Standards (SAS) No. 99 tentang Consideration of Fraud in a Financial Statement Audit. Tujuan dikeluarkannya SAS No. 99 adalah untuk meningkatkan efektivitas auditor dalam mendeteksi kecurangan dengan menilai pada faktor risiko kecurangan yang ada pada teori fraud triangle. Teori fraud triangle menyatakan bahwa terdapat tiga kondisi yang selalu hadir dalam kecurangan laporan keuangan, yaitu pressure (tekanan), opportunity (kesempatan), dan rationalization (rasionalisasi). Menurut SAS no. 99 terdapat beberapa jenis tekanan yang mungkin mengakibatkan kecurangan pada laporan keuangan. Salah satu dari jenis tekanan tersebut adalah Financial Stability.

Financial stability merupakan keadaan yang menggambarkan kondisi keuangan perusahaan berada pada kondisi yang stabil. Ketika suatu perusahaan berada dalam kondisi stabil maka nilai perusahaan akan naik dalam pandangan investor, kreditur dan publik. Oleh karena itu manajer akan melakukan berbagai cara agar financial stability perusahaan terlihat baik dan stabil. Stabilitas keuangan suatu perusahaan dapat dipengaruhi oleh beberapa hal antara lain seperti (1) salah saji (Misstatement) laporan keuangan, (2) munculnya peluang kecurangan (Opportunity Fraud) yang dapat dimanfaatkan oleh pihak - pihak yang ingin memperoleh keuntungan pribadi, (3) ketidakstabilan moneter suatu Negara, (4) terjadinya Inflasi, dan (5) kegagalan pasar.

Variabel financial stability ini digunakan untuk mengetahui seberapa besar aktiva yang ada di perusahaan. Perusahaan berusaha meningkatkan prospek perusahaan yang baik, melalui salah satunya dengan merekayasa informasi kekayaan aset yang berkaitan dengan pertumbuhan aset yang dimiliki (Skousen 
et al., 2008). Oleh karena itu, digunakan rasio perubahan total aset sebagai proksi pada variabel financial stability. Total aset menggambarkan kekayaan yang dimiliki oleh perusahaan. Semakin tinggi total aset yang dimiliki perusahaan menunjukkan kekayaan yang dimiliki semakin banyak. Tingginya aset yang dimiliki dapat menarik investor untuk berinvestasi pada perusahaan tersebut. Manajemen perusahaan akan memanipulasi laporan keuangan agar menampilkan pertumbuhan dan performa perusahaan meningkat. Persentase perubahan total aset mengindikasikan adanya kecurangan pada laporan keuangan, karena tingginya persentase perubahan total aset sebagai cara untuk menunjukkan earning power perusahaan dan posisi finansial yang lebih kuat (Mulford et al., 2010).

Menurut Wijoyo (2015) memperoleh hasil bahwa Financial Stability berpengaruh terhadap Financial Statement Fraud, dimana semakin tinggi total aset yang dimiliki perusahaan menunjukan kekayaan yang dimiliki semakin banyak. Tingginya asset yang dimiliki perusahaan menjadi daya tarik bagi investor. Tetapi diperoleh hasil lain dari penelitian yang dilakukan oleh Lia (2014) bahwa Financial Stability tidak berpengaruh positif terhadap Financial Statement Fraud. Hasil penelitian ini justru menunjukan Financial Stability tidak berpengaruh terhadap Financial Stability Fraud. Semakin tinggi atau rendahnya rasio perubahan total aset (ACHANGE) suatu perusahaan tidak dapat digunakan untuk mengetahui pengaruh terjadinya Financial Statement Fraud di dalam suatu perusahaan.

$\mathrm{H}_{1}$ : Financial stability berpengaruh positif pada misstatement laporan keuangan.

Selain itu menurut Wahyuni \& Budiwitjaksono, (2017) mencoba mendekteksi kecurangan dalam laporan keuangan dengan menggunakan perspektif fraud triangle. Penelitian tersebut menunjukan bahwa financial stability yang diproksikan dengan ACHANGE (asset change), financial target yang diproksikan dengan ROA (return on assets) dan external pressure yang diproksikan dengan FREEC (Free cash flow) berpengaruh signifikan terhadap kecurangan laporan keuangan. Sementara itu personal financial need yang diproksikan dengan IND (proporsi dewan komisaris independen) tidak berpengaruh signifikan terhadap kecurangan laporan keuangan. Berbeda dengan penelitian Rahmania, (2017) yang menguji pendeteksian kecurangan laporan keuangan dengan analisis fraud triangle yang diadopsi dalam SAS No.99 memperoleh hasil hanya faktor financial target yang berpengaruh signifikan terhadap kecurangan laporan keuangan. Berdasarkan penelitian - penelitian terdahulu tersebut, diduga ada variabel lain sehingga ingin mengetahui pengaruh Financial Stability dengan menggunakan Variabel Moderasi yaitu Opportunity Fraud.

Fraud secara garis besar adalah segala tindakan atau perbuatan yang dicirikan dengan pengelabuan, penipuan, penyalahgunaan atau melanggar kepercayaan untuk mendapatkan uang, aset, jasa atau untuk menjamin keuntungan atau manfaat pribadi dan bisnis. Fraud yang marak terjadi sekarang ini sebenarnya merupakan suatu perbuatan melawan hukum yang dilakukan oleh orang-orang dari dalam dan luar organisasi, dengan maksud untuk mendapatkan keuntungan pribadi dan kelompoknya yang secara langsung dapat merugikan pihak lain. Meningkatnya kasus skandal akuntansi menyebabkan berbagai pihak berspekulasi bahwa manajemen telah melakukan kecurangan atau manipulasi pada laporan keuangan (Skousen et al., 2008). 
Adapun beberapa hal yang dapat mempengaruhi terjadinya Fraud antara lain, Pressure (tekanan) dan Opportunity (peluang). Pressure (tekanan) merupakan hal yang menjadi pemicu adanya tindakan kecurangan (Fraud), karena pada dasarnya individu yang tertekan akan cenderung bertindak diluar batas nalar. Tindakan diluar batas nalar manajemen ini akan merugikan pihak prinsipal, baik pemilik perusahaan maupun pihak eksternal perusahaan seperti kreditur dan investor. Tekanan muncul karena adanya kewajiban yang harus diselesaikan. Tekanan pada porsi yang sesuai sebenarnya diperlukan oleh perusahaan untuk maju dan berkembang, akan tetapi tekanan yang berlebihan justru akan mengakibatkan munculnya keinginan untuk melakukan kecurangan demi memenuhi kebutuhan pribadi manajemen. Dalam SAS No. 99, terdapat empat jenis kondisi umum yang terjadi pada tekanan yang dapat mengakibatkan kecurangan. Kondisi tersebut adalah (1) tekanan stabilitas keuangan, (2) tekanan eksternal, (3) tekanan kebutuhan keuangan individu, dan (4) tekanan target keuangan. Opportunity adalah suatu peluang yang memungkinkan terjadinya Fraud atau tindakan kecurangan (Nabila, 2013). Para pelaku Fraud akan percaya bahwa aktivitas mereka tidak akan terdeteksi. Peluang dapat terjadi karena pengendalian internal yang lemah, pengawasan manajemen yang kurang baik atau melalui penggunaan posisi. Pada umumnya kesempatan untuk melakukan Fraud berdasarkan pada kedudukannya, manajemen suatu perusahaan memiliki potensi yang lebih besar untuk melakukan Fraud dibandingkan dengan karyawan. Tetapi patut digaris bawahi bahwa kesempatan untuk melakukan kecurangan selalu ada pada setiap kedudukan. Kegagalan dalam menetapkan prosedur yang memadai untuk kondisi Fraud juga mampu meningkatkan adanya Misstatement laporan keuangan. Dari ketiga elemen Fraud Triangle Theory, kesempatan memiliki kontrol yang paling atas dalam kasus misstatement laporan keuangan atau manipulasi laporan keuangan. Oleh karena itu dalam mendeteksi adanya aktivitas kecurangan maka perusahaan perlu membangun sebuah proses, prosedur dan kontrol yang efektif.

$\mathrm{H}_{2}$ : Opportunity fraud memperlemah pengaruh financial stability pada misstatement laporan keuangan.

Teori Fraud Triangle yang dicetuskan Clinard \& Cressey, (1954) sampai saat ini masih digunakan oleh para praktisi sebagai pendekatan dalam mendeteksi suatu tindak kecurangan. Pendekatan teori fraud triangle juga digunakan oleh Albrecht, (2010) untuk mengidentifikasi situasi yang menyebabkan perusahaan Chaebol di Korea dalam melakukan kecurangan. Hasil penelitian menunjukan adanya hubungan keluarga yang kuat di dalam perusahaan memainkan peran yang besar dalam hal tekanan dan kesempatan.

Auditor bertanggung jawab untuk mendekteksi salah saji material dalam laporan keuangan, kelemahan materil dalam pengendalian internal perusahaan serta mendekteksi adanya salah praktik kecurangan pelaporan laporan keuangan (SAS 1, AU 110). Terjadinya tindakan kecurangan laporan keuangan sering kali dimulai dari munculnya salah saji atau kacaunya manjemen laba dari laporan keuangan kuartal yang semulanya diabaikan dan dianggap tidak material tetapi pada akhirnya akan tumbuh menjadi Fraud secara besar - besaran yang kemudian akan menghasilkan sebuah laporan keuangan yang merugikan secara material. Accrual quality yang diproksikan dengan RSST, dan financial performance yang 
diproksikan dengan perubahan pada akun piutang, perubahan pada akun persediaan, perubahan pada akun penjualan tunai, dan perubahan pada EBIT adalah komponen variabel pada F-Score yang digunakan dalam mengukur kecurangan pada laporan keuangan.

Penelitian ini akan mengacu pada penelitian Skousen et al., (2008) untuk menguji kembali model pendektesian kecurangan pada lingkup perusahaan manufaktur di Indonesia. Jadi berdasarkan pernyataan tersebut, dicoba untuk menguji kembali proksi - proksi yang telah digunakan dalam penelitian sebelumnya. Selain itu, digunakan variabel Opportunity Fraud (kesempatan kecurangan) sebagai pemoderasi hubungan antara Financial Stability (stabilitas keuangan) pada Misstatement (kecurangan) laporan keuangan. Variabel pemoderasi yaitu Opportunity Fraud digunakan untuk mengetahui apakah variabel tersebut dapat memperlemah pengaruh Financial Stability pada Misstatement Laporan Keuangan dari perusahaan Manufaktur yang terdaftar di Bursa Efek Indonesia.

\section{METODE PENELITIAN}

Penelitian ini menggunakan pendekatan kuantitatif yang berbentuk asosiatif. Penelitian kuantitatif merupakan penelitian yang lebih menekankan pengujian teori melalui pengukuran variabel penelitian dengan angka serta data yang dianalisis menggunakan prosedur statistik (Supomo \& Indriantoro, 2012). Penelitian ini dalam berbentuk asosiatif yaitu penelitian yang bertujuan untuk mengetahui hubungan antara dua variabel atau lebih (Sugiyono, 2013:11). Dalam penelitian ini menggunakan tiga variabel yang terdiri dari variabel dependen yaitu misstatement laporan keuangan, variabel independen yaitu financial stability pressure dan variabel moderasi yaitu opportunity fraud. Berdasarkan pemaparan tersebut, kerangka pemikiran yang dapat disajikan dapat dilihat dalam Gambar 1 berikut.

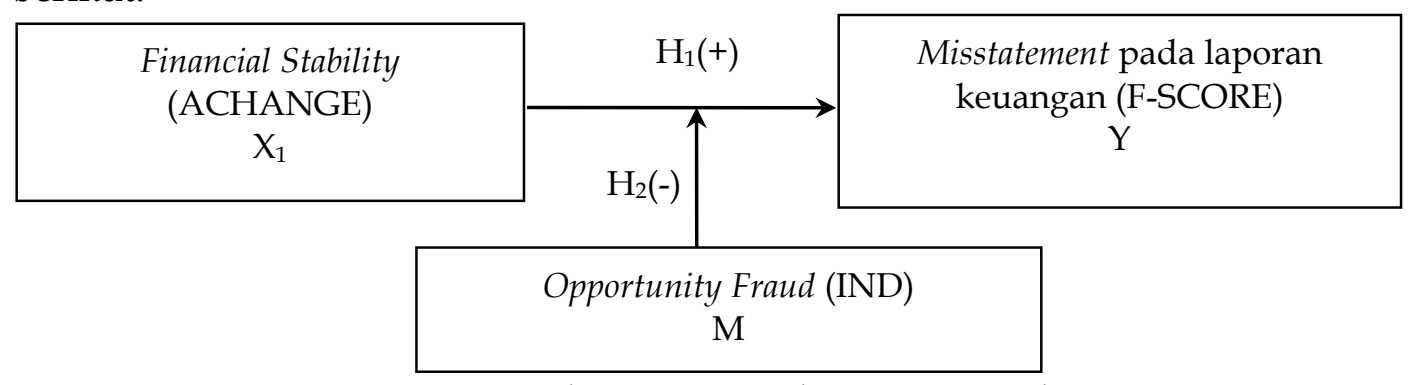

Sumber: Kajian Penelitian Terdahulu, 2019

\section{Gambar 1. Kerangka Konseptual}

Penelitian ini dilakukan pada Bursa Efek Indonesia (BEI) yang memiliki data-data keuangan perusahaan khususnya perusahaan manufaktur. Alasan menggunakan tempat penelitian pada Bursa Efek Indonesia karena sebagian besar informasi mengenai perusahaan manufaktur yang telah go public dapat di akses pada Bursa Efek Indonesia. Selain data yang diperoleh tersedia dengan lengkap dikarenakan perusahaan yang terdaftar pada Bursa Efek Indonesia wajib mempublikasikan laporan keuangan tahunan paling lambat pada akhir bulan ketiga setelah tahun buku berakhir dalam situs resmi BEI. 
Variabel terikat dalam penelitian ini adalah Financial Stability (Y) yang diproksikan dengan ACHANGE yang merupakan rasio perubahan aset selama dua tahun. Variabel bebas dalam penelitian ini adalah Misstatement Laporan Keuangan $\left(\mathrm{X}_{1}\right)$ yang diproksikan dengan RSST accrual. Variabel moderasi dalam penelitian ini adalah Opportunity Fraud / Peluang Kecurangan (M) yang diproksikan dengan proporsi komite audit independen (IND).

Sampel yang digunakan dalam penelitian ini dipilih secara purposive sampling, sehingga sampel yang digunakan dalam penelitian lni merupakan representasi dari populasi sampel yang ada serta sesuai dengan tujuan dari penelitian. Data sekunder yang diperoleh kemudian diseleksi sesuai dengan kriteria yang sudah di tentukan. Dari 154 perusahaan manufaktur yang terdaftar di Bursa Efek Indonesia pada tahun 2015-2018 terdapat 77 perusahaan yang memenuhi kriteria purposive sampling untuk dijadikan sampel penelitian yang ditampilkan pada Tabel 1.

Tabel 1. Jumlah Populasi dan Sampel

\begin{tabular}{|c|c|c|}
\hline No & Keterangan & Jumlah \\
\hline & Perusahaan manufaktur yang terdafatar di BEI pada tahun 2015-2018 & 154 \\
\hline 1) & $\begin{array}{l}\text { Kriteria : } \\
\text { Perusahaan yang tidak mempublikasikan laporan tahunan lengkap } \\
\text { selama tahun 2015-2018 }\end{array}$ & $(16)$ \\
\hline 2) & Perusahaan yang mengalami kerugian selama periode $2015-2018$ & $(22)$ \\
\hline 3) & $\begin{array}{l}\text { Perusahaan yang tidak menyebutkan jumlah komite audit } \\
\text { independen }\end{array}$ & $(14)$ \\
\hline \multirow[t]{3}{*}{ 4) } & $\begin{array}{l}\text { Perusahaan yang tidak menggunakan mata uang rupiah dalam } \\
\text { laporan keuangannya }\end{array}$ & $(24)$ \\
\hline & Jumlah perusahaan yang digunakan sebagai sampel & 77 \\
\hline & Jumlah data (77 perusahaan $\times 4$ tahun pengamatan) & 308 \\
\hline
\end{tabular}

Sumber: Data Penelitian, 2019

Data selanjutnya di analisis menggunakan Moderated Regression Analysis (MRA). Persamaan regresi yang digunakan dalam penelitian ini adalah awbagai berikut.

F-Score $=\alpha_{0}+\beta_{1}$ ACHANGE $+\beta_{2}$ IND $+\beta_{3}$ ACHANGE ${ }^{*}$ IND $+\varepsilon$

Keterangan:

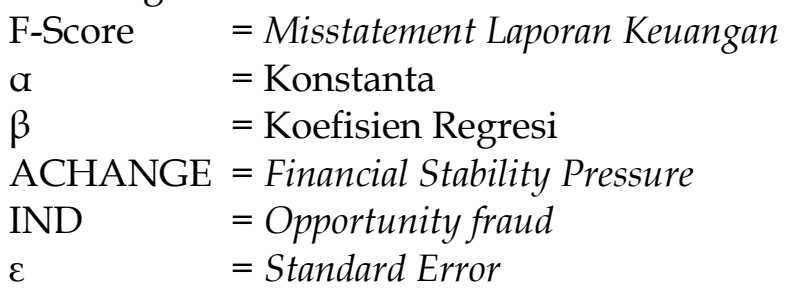

\section{HASIL DAN PEMBAHASAN}

Statistik deskriptif memberikan informasi mengenai karakteristik variabel penelitian yang terdiri atas jumlah pengamatan, nilai minimum, nilai maksimum, nilai mean, dan standar deviasi. Tabel 2, menunjukkan hasil statistik deskriptif. 
Tabel 2. Hasil Statistik Deskriptif

\begin{tabular}{|c|c|c|c|c|c|}
\hline & $\mathrm{N}$ & Minimum & Maximum & Mean & Std. Deviation \\
\hline $\begin{array}{l}\text { Financial Stability } \\
\text { (AChange) }\left(\mathrm{X}^{1}\right)\end{array}$ & 308 & $-0,780$ & 0,530 & 0,0604 & 0,138 \\
\hline $\begin{array}{l}\text { Opportunity (IND) } \\
\left(\mathrm{X}^{2}\right) \\
\text { Misstatement }\end{array}$ & 308 & 0,200 & 0,500 & 0,3291 & 0,031 \\
\hline $\begin{array}{l}\text { Laporan Keuangan } \\
\text { (F Score) (Y) }\end{array}$ & 308 & $-568133686,20$ & 191940044,20 & $-805047,1609$ & 68017057,00385 \\
\hline $\begin{array}{l}\text { AChange*IND } \\
\text { Valid N (listwise) }\end{array}$ & $\begin{array}{l}308 \\
308\end{array}$ & $-0,260$ & 0,180 & 0,0196 & 0,045 \\
\hline
\end{tabular}

Sumber: Data Penelitian, 2019

Tabel 2, menunjukkan bahwa variabel misstatement laporan keuangan (Y) memiliki nilai minimum sebesar -56813 , nilai maksimum sebesar 19194, mean sebesar -80604, dan standar deviasi sebesar 68017. Hal ini menunjukkan terjadi perbedaan nilai misstatement laporan keuangan yang diteliti dengan nilai rataratanya sebesar 68017. Variabel financial stability (ACHANGE) $\left(\mathrm{X}_{1}\right)$ memiliki nilai minimum sebesar -78, nilai maksimum sebesar 53, mean sebesar 0604 dan standar deviasi sebesar 13815. Hal ini menunjukkan terjadi perbedaan nilai financial stability yang diteliti dengan nilai rata-ratanya sebesar 13815.Variabel opportunity fraud $\left(X_{2}\right)$ memiliki nilai minimum sebesar 20, nilai maksimum sebesar 50, mean sebesar 3291, dan standar deviasi sebesar 03062. Hal ini menunjukkan terjadi perbedaan nilai opportunity fraud yang diteliti dengan nilai rata-ratanya sebesar 0,3062 .

Untuk mengetahui apakah variabel Opportunity fraud mampu memoderasi pengaruh variabel Financial Stability Pressure terhadap Misstatement Laporan Keuangan, maka digunakan model pengujian interaksi (Moderated Regression Analysis-MRA). Model ini bertujuan untuk mengetahui apakah variabel moderasi mampu mempengaruhi hubungan antara variabel bebas dan variabel terikat, dimana dalam persamaan regresinya mengandung unsur interaksi. Hasil analisis uji interaksi dengan menggunakan program SPSS dapat dilihat pada Tabel 3.

Tabel 3. Hasil Uji Interaksi (Moderated Regression Analysis)

\begin{tabular}{|c|c|c|c|c|c|}
\hline \multirow[t]{2}{*}{ Model } & \multicolumn{2}{|c|}{$\begin{array}{l}\text { Unstandardized } \\
\text { Coefficients }\end{array}$} & \multirow{2}{*}{$\begin{array}{c}\begin{array}{c}\text { Standardized } \\
\text { Coefficients }\end{array} \\
\text { Beta }\end{array}$} & \multirow[b]{2}{*}{$\mathrm{t}$} & \multirow[b]{2}{*}{ Sig. } \\
\hline & B & Std. Error & & & \\
\hline 1 (Constant) & $-0,062$ & 0,020 & & $-3,105$ & 0,002 \\
\hline AChange & 0,409 & 0,059 & 0,498 & 6,880 & 0,000 \\
\hline IND & 0,304 & 0,045 & 0,334 & 6,760 & 0,000 \\
\hline AChange*IND & $-0,151$ & 0,066 & $-0,166$ & $-2,279$ & 0,023 \\
\hline R Square & & & & & 0,275 \\
\hline Adjusted R Square & & & & & 0,268 \\
\hline F Hitung & & & & & 38,407 \\
\hline Signifikansi F & & & & & 0,000 \\
\hline
\end{tabular}

Sumber: Data Penelitian, 2019

Berdasarkan hasil analisis regresi linier berganda seperti yang disajikan pada Tabel 3, maka persamaan strukturalnya adalah sebagai berikut.

F-Score $=-0,062+0,409$ ACHANGE + 0,304 IND - 0,151 ACHANGE*IND

Nilai koefisien regresi variabel Financial Stability dan Opportunity fraud bernilai positif dengan nilai signifikansi uji $t$ kurang dari 0,05. Hal ini 
menunjukkan bahwa variabel Financial Stability memiliki pengaruh positif yang signifikan terhadap variabel terikat. Sedangkan Nilai koefisien regresi variabel Interaksi antara Financial Stability dengan Opportunity fraud bernilai negatif dengan nilai signifikansi uji $t$ lebih dari 0,05 . Hal ini menunjukkan bahwa variabel Interaksi antara Financial Stability dengan Opportunity fraud berpengaruh secara negatif signifikan terhadap variabel terikat.

Hasil uji koefisien determinasi dalam Tabel 3, menunjukkan besarnya nilai adjusted $\mathrm{R}^{2}$ adalah sebesar 0,268. Ini berarti variasi Misstatement Laporan Keuangan dapat dipengaruhi secara signifikan oleh variabel Financial Stability, Opportunity fraud, dan variabel Interaksi antara Financial Stability dengan Opportunity fraud sebesar 26,8 persen sedangkan sisanya sebesar 73,2 persen dijelaskan oleh faktorfaktor lain.

Hasil uji $\mathrm{F}$ (F-test) menunjukkan bahwa nilai signifikansi $\mathrm{P}$ value 0,000 yang lebih kecil dari $\alpha=0,05$, ini berarti model yang digunakan pada penelitian ini adalah layak. Hasil ini memberikan makna bahwa seluruh variabel independen yaitu Financial Stability, Opportunity fraud, dan variabel Interaksi antara Financial Stability dengan Opportunity fraud mampu memprediksi atau menjelaskan fenomena Misstatement Laporan Keuangan pada perusahaan manufaktur yang sudah terdaftar di Bursa Efek Indonesia tahun 2015-2018. Hal ini berarti model dapat digunakan untuk analisa lebih lanjut atau dengan kata lain model dapat digunakan untuk memproyeksikan karena hasil goodness of fitnya baik dengan nilai signifikansi P value 0,000.

Berdasarkan hasil analisis pengaruh Financial Stability pada misstatement laporan keuangan diperoleh nilai signifikasi sebesar 0,000 dengan nilai koefisien regresi positif sebesar 0,409. Nilai Signifikansi 0,000 $<0,05$ mengindikasikan bahwa $\mathrm{H}_{1}$ diterima. Hasil ini mempunyai arti bahwa Financial Stability berpengaruh positif terhadap misstatement laporan keuangan. Terdukungnya hipotesis ini mengindikasi bahwa semakin tinggi total aset yang dimiliki perusahaan menunjukkan kekayaan yang dimiliki semakin banyak. Tingginya aset yang dimiliki perusahaan dapat menarik investor untuk berinvestasi pada perusahaan tersebut. Manajemen perusahaan akan memanipulasi laporan keuangan agar menampilkan pertumbuhan dan performa perusahaan semakin meningkat.

Hasil ini sesuai dengan penelitian (Skousen et al., 2008) dan (Nabila, 2013). Menurut Skousen et al., (2008) manajer dapat terdorong untuk melakukan tindakan fraud ketika stabilitas keuangan terancam oleh keadaan ekonomi dan hal tersebut dapat terjadi karena dengan menurunnya stabilitas keuangan suatu perusahaan maka kinerja suatu perusahaan akan terlihat menurun dimata publik sehingga dapat menghambat aliran dana dan investasi tahun mendatang (Nabila, 2013).

Teori Keagenan menyatakan bahwa perusahaan yang memisahkan fungsi pengelolaan dan kepemilikan akan rentan terhadap konflik keagenan. Pada model keagenan dirancang sebuah sistem yang melibatkan kedua belah pihak yaitu manajemen dan pemilik. Selanjutnya manajemen dan pemilik akan melakukan kontrak kerja untuk mencapai hasil yang diharapkan. Stock \& Lambert, (2001) menyatakan bahwa dalam kontrak tersebut diharapkan dapat memaksimumkan hasil pemilik, dan dapat memuaskan atau menjamin manajemen untuk menerima 
reward. Sesuai dengan agency theory dimana motivasi manajemen dapat dikelompokan dalam 2 kategori yaitu (1) Opportunistic dan (2) Signaling Theory. Pada motivasi opportunistic manajemen melalui kebijakan aggresive accounting dapat menghasilkan angka laba lebih tinggi dari pada laba yang sesungguhnya. Apabila nantinya laporan laba tidak dapat menggambarkan laba yang sesungguhnya, maka laporan laba dapat mengarah kepada Ovestate Earnings. Laba yang mengarah pada Overstate Earning dapat mengakibatkan laba menjadi dapat dimanipulasi.

Berdasarkan hasil uji analisis regresi moderasi, pada Tabel 3, menunjukkan pengaruh Financial Stability pada Misstatement Laporan Keuangan $\left(b_{1}\right)$ diperoleh nilai signifikansi sebesar 0,000 (significant) dengan nilai koefisien regresi sebesar 0,409. Nilai signifikansi variabel moderasi Opportunity fraud pada Misstatement Laporan Keuangan $\left(\mathrm{b}_{2}\right)$ sebesar 0,000 (significant) dan nilai signifikan variabel Interaksi antara Financial Stability dengan Opportunity fraud pada Misstatement Laporan Keuangan $\left(b_{3}\right)$ signifikan sebesar 0,023, hal ini mengindikasikan variabel moderasi merupakan tipe moderasi sebagian (quasi moderator), karena koefisien $\mathrm{b}_{2}$ significant dan koefisien $\mathrm{b}_{4}$ significant. Quasi moderator merupakan variabel yang memoderasi hubungan antara variabel prediktor dan variabel tergantung di mana variabel moderasi semu berinteraksi dengan variabel prediktor sekaligus menjadi variabel prediktor. Artinya, variabel Opportunity Fraud dapat menjadi variabel moderasi dan juga dapat menjadi variabel bebas (Solimun, 2010:33). Untuk melihat apakah variabel moderasi Opportunity fraud memperkuat atau memperlemah pengaruh Financial Stability (X) terhadap Misstatement Laporan Keuangan (Y).

Hasil analisis regresi moderasi pada Tabel 3, menunjukkan bahwa nilai koefisien regresi Financial Stability $\left(\beta_{1}\right)$ positif signifikan dan variabel Interaksi antara Financial Stability dengan Opportunity fraud $\left(\beta_{3}\right)$ negatif signifikan, maka variabel Opportunity fraud (M) merupakan variabel moderasi yang memperlemah pengaruh Financial Stability pada Misstatement Laporan Keuangan. Terdukungnya hipotesis ini mengindikasi bahwa hal ini menunjukan keadaan yang dapat terjadi ketika para manajer tidak serta - merta memanipulasi laporan keuangan untuk meningkatkan prospek perusahaan ketika rata - rata pertumbuhan berada dibawah rata - rata industri seperti yang diungkapkan oleh Loebbecke et al., (1989) sehingga akan memperparah kondisi keuangan perusahaan di masa mendatang. Keadaan demikian akan mempersulit perusahaan dalam menerima bantuan atau investasi dari pihak eksternal maumpun internal untuk menyelamatkan perusahaan mereka ketika terancam kondisi ekonomi global sehingga membuat perusahaan sulit berkembang dan semakin buruk di masa depan.

Hasil penelitian ini sejalan dengan Skousen et al., (2008) yang menyatakan ketika suatu perusahaan sedang berada dalam keadaan yang stabil, maka nilai perusahaan akan naik dalam pandangan investor, kreditur, dan publik. Oleh karena itu, pihak manajemen akan melakukan berbagai cara agar financial stability perusahaan terlihat baik. Hal inilah yang menjadi tekanan bagi manajer untuk menampilkan kondisi perubahan aset yang stabil dan menunjukkan stabilitas perusahaan yang terlihat baik kepada para pengguna laporan keuangan dengan melakukan manipulasi, sebagai upaya untuk menarik minat investor untuk menanamkan modal diperusahaannya. 
Agency Theory yang dikemukakan oleh Jensen dan Mecling dalam Diany \& Ratmono, (2014) menyatakan dimana suatu perusahaan, manajer perperan sebagai agen yang bertanggung jawab dalam mengoptimalkan dan memaksimalkan keuntungan yang akan didapat oleh prinsipal selaku pemilik dan pemegang saham diperusahaan. Namun disisi lain agen yang diberi amanat oleh prinsipal berupa kepercayaan dan tanggung jawab suatu perusahaan juga memiliki tugas untuk memaksimalkan kesejahteraan agen tersebut. Agen sebagai manajemen merupakan pihak yang dikontrak atau dipekerjakan oleh pemegang saham untuk bekerja demi kepentingan prinsipal. Oleh karena itu, agen diberikan kekuasaan didalam mengatur dan membuat keputusan yang terbaik bagi kepentingan prinsipal dan perusahaannya. Sebagai bentuk tanggung jawab agen kepada prinsipal, agen berkewajiban untuk mempertanggung jawabkan hasil kerjanya kepada prinsipal yang biasanya di implementasikan dalam laporan keuangan perusahaan dan laporan manajerial. Menyadari dengan pentinganya kandungan informasi yang ada pada laporan tersebut, maka manajer menjadi termotivasi untuk meningkatkan kinerja perusahaan sehingga dengan cara seperti itu manajer dapat menjaga eksistensinya serta mendapatkan tunjangan atau bonus yang lebih besar lagi. Namun pada kenyataannya yang terjadi dilapangan menunjukan bahwa beberapa manajer gagal didalam mencapai tujuan kinerjanya sehingga informasi yang akan dipublikasikan didalam laporan keuangan tersebut tidak dapat memuaskan beberapa pihak khususnya prinsipal selaku pemegang saham dan pemilik perusahaan. Maka dengan demikian karena adanya permasalahan tersebut terkadang manajemen rela melakukan kecurangan supaya informasi dalam laporan keuangan dapat terlihat baik dan dapat membantu agen dalam memenuhi kepentingannya. Tekanan merupakan pemicu utama terjadinya sutau tindakan kecurangan. Tekanan yang diterima akan membuat seseorang melakukan tindakan melanggar aturan demi menghindari ataupun untuk mengatasi tekanan tersebut.

\section{SIMPULAN}

Simpulan penelitian ini yaitu Financial stability berpengaruh positif pada misstatement laporan keuangan perusahan manufaktur yang terdaftar di BEI tahun 2015-2018. Hal ini menunjukan pihak manajemen akan melakukan berbagai cara agar financial stability perusahaan terlihat baik dengan cara melakukan manipulasi laporan keuangan. Simpulan kedua yakni Opportunity Fraud memperlemah pengaruh Financial Stability pada Misstatement Laporan Keuangan perusahaan manufaktur yang terdaftar di BEI tahun 2015 - 2018. Hal ini menunjukan bahwa Peluang kecurangan dapat memperlemah kestabilan keuangan suatu perusahaan. Bila suatu perusahaan sedang mengalami ketidakstabilan keuangan maka manajer selaku agen akan melakukan manipulasi laporan keuangan agar laporan keuangan suatu perusahaan dapat terlihat baik bagi investor.

Berdasarkan hasil penelitian dan simpulan maka pihak manajemen dalam hal ini agent diharapakan untuk lebih bertanggung jawab dalam melindungi kepentingan principle dalam hal ini investor mengenai dampak dari tindakan misstatement dalam laporan keuangan. Kemudian, para investor dan calon investor diharapkan lebih mempertimbangkan faktor-faktor yang mempengaruhi 
terjadinya kecurangan sehingga investor dapat mendeteksi adanya laporan keuangan yang bermasalah.

\section{REFERENSI}

ACFE. (2002). Report the Nation. Austin, USA, 111(479), 1009-1010. https:// doi.org/10.1192/bjp.111.479.1009-a

AICPA. (2002). Statement on Auditing Standards No. 99, Consideration of Fraud in Financial Statement Audit. New York: AICPA.

Albrecht, S. L. (2010). Handbook of Employee Engagement. Cheltenham: Edward Elgar Publishing Limited.

Bapepam. (2002). Independensi Akuntan Yang Memberikan Jasa Audit Di Pasar Modal. file:/ / / D:/Documents/Download/kep_bapepam_kep20pm2002_lampiran. pdf

Clinard, M. B., \& Cressey, D. R. (1954). Other People's Money: A Study in the Social Psychology of Embezzlement. American Sociological Review. https://doi.org/10.2307/2087778

Diany, Y. A., \& Ratmono, D. (2014). Determinan Kecurangan Laporan Keuangan: Pengujian Teori Fraud Triangle. Diponegoro Journal of Accounting, 3(2), 10481056.

https://ejournal3.undip.ac.id/index.php/accounting/article/view/6186

Koroy, T. R. (2008). Pendeteksian Kecurangan (Fraud) Laporan Keuangan oleh Auditor Eksternal. Jurnal Akuntansi Dan Keuangan, 10(1), 22-33. https://jurnalakuntansi.petra.ac.id/index.php/aku/article/view/17000

Lia, K. L. (2014). Pengaruh Financial Stability, Eksternal Pressure, Personal Financial Need, Financial Targets dan Inefective Monitoring pada Financial Fraud dalam Prespektif Fraud Triangle. Universitas Sanata Dharma Yogyakarta, 53(9), 1689-1699. https:/ / doi.org/10.1017/CBO9781107415324.004

Loebbecke, J., Eining., M., \& Willingham, J. (1989). Auditor's Experience with Material Irregularities: Frequency, Nature, and Detectability. Auditing: A Journal of Practice \& Theory, Fall:1-28.

Mulford, C. W., Comiskey, E. E., Harahap, A. S., \& Anggraeni, Y. D. (2010). Deteksi Kecurangan Akuntansi, The Financial Numbers Game. Jakarta: Penerbit PPM.

Nabila, A. R. (2013). Deteksi Kecurangan Laporan Keuangan dalam Perspektof Fraud Triangle. Universita Diponegoro.

Rahmania, A. (2017). Pendeteksian Kecurangan Laporan Keuangan Dengan Analisis Fraud Triangle yang diadopsi dari SAS no 99.99.

Rohana, K., Iberahim, H., \& Shabudin, A. (2012). Willingness to Pay for Halal Logistics: The Lifestyle Choice. Procedia - Social and Behavioral Sciences, 722729. https://doi.org/10.1016/j.sbspro.2012.08.075

Satriyo Adhimas, W. (2015). Pengaruh Financial Stability, Personal Financial Need dan Inefective Monitoring terhadap Financial Stability Fraud pada perusahaan perbankan yang terdaftar di Bursa Efek Indonesia. Fakultas Ekonomi Universitas Widyatama Bandung, 111(479), 1009-1010. https://doi.org/10.1192/bjp.111.479.1009-a

Skousen, C. J., Smith, K. R., \& Wright, C. (2008). Detection Fraud of Financial Statement with Fraud Triangle. Corporate Finance: Governance, 13, 53-81. https://doi.org/https://doi.org/10.2139/ssrn.1295494 
Stock, \& Lambert. (2001). Strategic Logistics Management. 4th Edition, McGraw Hill, New York.

Sugiyono. (2013). Metode Penelitian Pendidikan Pendekatan Kuantitaif, Kualitatif, dan RED. Bandung: Alfabeta. https://doi.org/10.1007/s13398-014-0173-7.2

Supomo, B., \& Indriantoro, N. (2012). Metodologi Penelitian Bisnis Untuk Akuntansi dan Manajemen. Yogyakarta: BPFE.

Wahyuni, \& Budiwitjaksono, G. S. (2017). Fraud Triangle sebagai Pendeteksian Kecurangan Laporan Keuangan. Jurnal Akuntansi, XX(1), 47-61. 